\title{
Total Factor Productivity and Economic Growth of Pakistan: A Time Series Analysis
}

\author{
GHULAM YAHYA KHAN \\ Assistant Professor, Kashmir Institute of Economics, \\ UAJ\&K, Muzaffarabad, Pakistan. \\ Email: yqureshi79@gmail.com \\ MEHRAN DIN MUHAMMAD \\ M.Phil Scholar, Kashmir Institute of Economics, \\ UAJ\&K, Muzaffarabad, Pakistan. \\ SALIK MEHBOOB \\ M.Phil. Scholar, Kashmir Institute of Economics, \\ UAJ\&K, Muzaffarabad, Pakistan.
}

\begin{abstract}
The investigation of contribution of total factor productivity to economic-growth for Pakistan for period 1978-2019 was objective of current article. Johanson and Jusilies (1988, 1995) Co integration technique has been used to estimate the growth equation. Using growth accounting approach for estimation of total factor productivity. Labour force, physical-capital, human-capital and trade openness used as a set of control variables. To study the serial correlation we have use LM test. Wald test have been use as a coefficient diagnostic that have reported the existence of the short run relations ship also among the variable(s). The Granger-Causality test measure Causality of variables that shows some of variables had a Bi-directional causality and some of them have uni-directional causality. The study used collected data from world development indicators. In the particular, study found that there is long run relationship in TFP and Economic-growth as well as in short-run. This study is (i) among one of very few country specific investigations exploring Total Factor productivity (TFP) and growth nexus (ii) Using an advanced time series technique on most recent data set.
\end{abstract}

Keywords: Economic Growth, Cointegration, human capital, trade openness, Granger Causality, Pakistan.

\section{Introduction}

One of the prevalent discussions of the all economies is to identify that how much of total output is produced by the human and physical capital and how much of output produced by the other factors like institutions and adopted technology. In economic literature there is a little suspicion about the valuable influence of higher human and physical capital on the economic growth, most of economist claimed that the continuous high economic growth depend upon the sustained technology and as well as on institutional growth in the economy. Based upon the assumption of perfect competition and constant returns to scale. There is a lot of discussion about interesting question of sources of economic growth, chief amongst them is Total Factor Productivity.

Total Factor Productivity (TFP) is the share of output not explained by amount of inputs used in production. As such, its level is determined by how efficiently and intensely the inputs are utilized in 
production. Physical-capital, human-capital, and technology are sources of TFP. TFP growth is usually measured by Solow residual, as was first discussed by Solow (1956-58) and modified production function in Hicks-Netural form: $Y=A$. $F(K, L)$. It expresses that the ratio of marginal product remains same for a given capital and labor ratio. According to Kemal et al., (2002), practically one-third of the growth in GDP can be accounted for by growth in productivity. Similarly, by (Groskopf and Self, 2006) growth based on factor accumulation was not as strong as based on human capital. Furthermore, productivity estimations are familiar for consequence of business cycles and inflation. So, it can be a reliable source for policy makers (Kong and Tongzon, 2006). Figure 1 below shows that in 1978-1982 and 2003-2007 Pakistan attained higher level of TFP growth particularly in 2007.

Figure 1: Total factor productivity 1973-2007

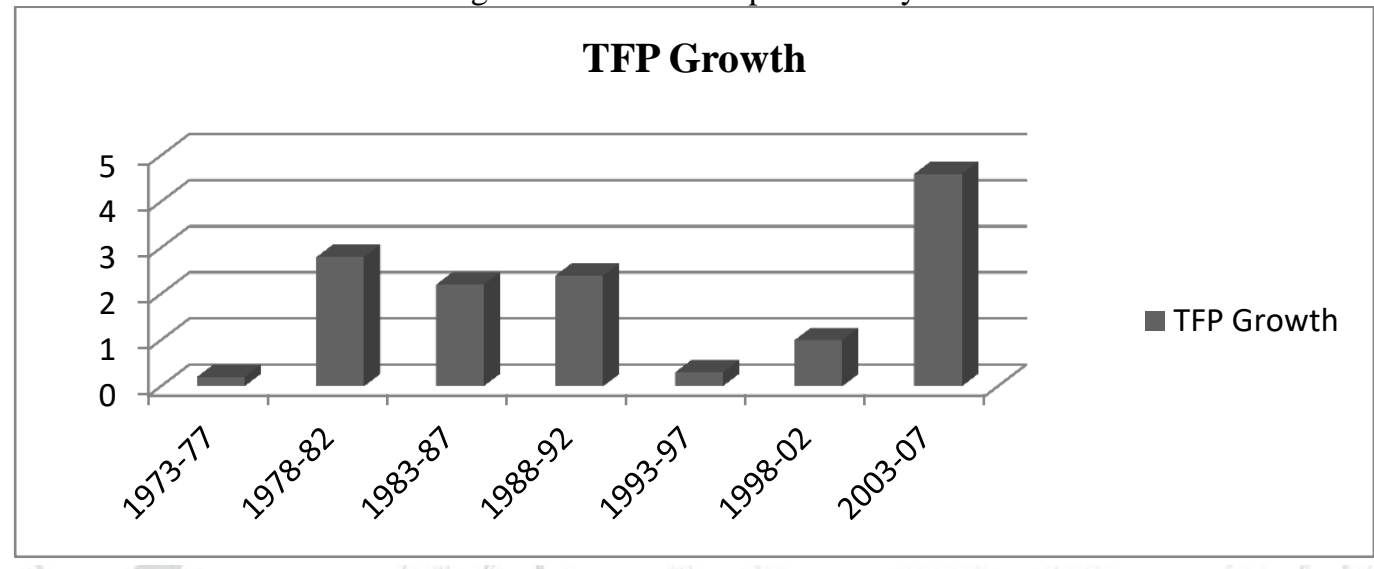

Keeping in view importance role of TFP in growth we formulate our objectives, research question(s) and hypothesis respectively as follows;

To examine the influence of TFP in economic growth of Pakistan and suggest suitable policy implications. Whether or not Total Factor Productivity has significantly affected the economic growth of Pakistan? Ho: Total Factor Productivity has significant effect on economic growth of Pakistan.

There are a lot of studies which had used total factor productivity analysis for different data set. Most of the Industrial studies include Baldwin and Rafiquzzaman (1994), Rao and Shandre (1998), Bjurek and Durevall (2000), Fare et al., (2001), Mahadevan (2002), Idris and Rehmah (2006), Diaz and Sanchez (2008). In economic literature the role of productivity growth in improving the economic growth is very crucial. In neo-classical growth accounting setup, the total output growth is a return of, the growth of inputs accumulation and the growth of productivity or efficiency. Consequently, for existing combination of factor inputs (capital, land and labor), and the changes in the production function are enthused by developments in the efficiency. The technological progress is being considered as an exogenous procedure in the neoclassical framework, for instance the Ramsay Optimal Growth Models (1928) and Samuelson Overlapping Generation Models, (1958) Slow Growth Model (1956), and their supporters. These all models have been dared by the endogenous growth thinkers, who assume that the technological process is an endogenous process in the growth and can be estimated as TFP. The endogenous technological procedure permits government strategies to shake technological process which in turn will be imitated in TFP and hence in growth. These policies have emotional impact on TFP through human capital endowments of employed labor force, given that better physical infrastructure and other assistance to include technology in the production process. The productivity differences are also important for policymakers because the TFP is the key source of economic growth. The productivity change is usually accrued due to two factors. First one is in the production process the adoption of technical innovation, like other developing countries Pakistan also adopted from advanced countries, and the other is ability of firms 
to rise production with given technology and inputs. A productivity evaluation between diverse sectors can also lead to cause of industrial growth and will also help in allocation of resources to different sectors (Bukhari et al 2005). There is scarce work that tried to describe the factor of TFP growth. Certain other studies like Grilick (2000) have include side discussion of determinants of TFP in Pakistan Pasha et al., (2002) Sabir and Ahmed (2003). Husna et al., (2009) examines the influence of foreign ownership on TFP for food and tobacco and financial business sectors of Pakistan. Sadia et al., (2010) practically investigated the association among TFP and Trade liberalization. The Major problem of the studies relating to Pakistan is their incapability of addressing the TFP and Economic growth. All the studies in recent decade evaluate the TFP growth in small scale and most of base on large scale manufacturing industries. These studies cannot evaluate TFP as the key element of long-run economic growth in case of Pakistan. There are number of studies that capture the total factor productivity growth and efficiency in Agriculture sector (Azam, 2007), But in case of Pakistan now agriculture sector is no longer the key producing sector. This study enhances to the current estimates for Pakistan by calculating TFP on the first stage through growth accounting process, and on the next stage tries to analysis the relationship among economic growth and TFP in long run with co-integration.

This paper is structured into five sections, starts with an introduction section followed by the literature review, methodology and data, results and discussions, and finally conclusion section.

\section{Literature Review}

This review describes many factors that have relationship with the of TFP growth. Some of these are, infrastructure, human capital (health and education), financial development, openness, competition, imports, geography and capital deepening. In the industrial countries Innovations and R\&D had been considered essential for TFP growth, as against the case of less developing countries. Sectoral and subsectorial analysis of economy also show long run nexus among output and TFP (Khan et al., 2019). There are two different opinions about the economic growth. One is the "accumulationist view". Accumulation of resources related with the traditional growth. The other one, called the "revisionist" a response to the traditional, oppose accumulation and argues efficiency behind economic growth like Asian tigers miracle (Han, 2003).

Solow (1956) and Rodriguez-Clare (1997) confirmed that technology is the only thing that may create essential cross-country variances in term of income per capita. Hall and Jones (1999) concluded that, TFP is very important for sustained economic growth process. In similar way, some studies have emphasized the need for inclusive growth to experience smooth growth in developing countries through fiscal factors, human capital and capital formation (Anwar et al., 2019; Aslam et al., 2019). According to "Atkinson and Stiglitz (1969) TFP is insufficient to few sectors of the economy. According to Edwards, (1993, 1997); Grossman and Helpman, (1990, 1991)"; (Demurger, 2000) a significant relationship between trade openness and total factor productivity growth was good source for growth. Conversely, according to Young (1992); "Kim and Lau (1994); Ben and Spiegel (1994)"; Young (1995) TFP growth was result of growth of factor accumulation. But the studies like Romer, and Weil (1992) Islam (1995); Miller and Upadhya (2000) and Rauf et al., (2017) opinioned human capital has significant effect on total factor productivity.

Studies like Fare et al., (1995); Jones and Williams (1998); and Comin (2002) concluded that R\&D has valuable impacts on TFP. Mayer (2001) argued that trade based on imports in such a way by introducing foreign technology into national production that leads to significance effect on TFP while some conclude that De-industrialization had negative effects for growth and development through lower TFP (Khan et al., 2018). There is significant relationship between TFP growth and international trade (Fatima et al., 2003).

Chanda and Dalsgaard (2003) argued a correlation among TFP and institutions because the intuitions usually regulate the agricultural as well as non-agricultural structure of the country. While Fue (2005) established that productive domestic market and neutral outward sloping policy is essential for exports to 
produce valuable influence on growth of TFP. Moreover, foreign direct investment has vital role in growth of TFP (Khan, 2006).

Comin, et al., (2006) identified cross-country differences in physical capital could determine the crosscountry differences in TFP. Small and medium size firms were more efficient than large (Diaz and Sanchez, 2008). According to Azam (2009) findings of Sectoral TFP analysis suggested that Pakistan has higher average growth rates in comparison of other developing and regional countries but lies below the East Asian Countries.

Recent studies have added different aspects that effect the growth through increasing total factor productivity. Literature survey evidenced the need of exploring TFP and growth nexus further as it remained a major and significant source of growth and development in most of developed countries of the world

\section{Methodology and Data}

Empirical model testing starts following Solow and Swan (1956) while TFP is assessed through the remaining term in the production function.

$$
Y(t)=F(K(t), L(t), A(t))
$$

Taking aggregate production function in neoclassical form to estimate the growth of TFP in growth accounting-framework is given as follows:

$$
Y_{t}=F\left(K_{t}, L_{t}, t\right)
$$

From the equation above, $Y_{t}$ is output $K_{t}$ is capital and $L_{t}$ is labor input in physical units and t shows the time in production function. Constant returns to scale are assumed by the function $\mathrm{F}$ over time, technical changes shift the function in above model. In economics these changes are known as growth in total factor productivity (GTFP). This production function given in equation (2) now can be written in Hicks-neutral form as:

$$
Y_{t}=A(t) F\left(K_{t}, L_{t}\right)
$$

More inputs mean more output implying marginal product of labour (MPL) and the marginal product of capital (MPK) are both positive. While output (Y) depends on inputs and level of technology (A) in above equation.

So, following base line model will be used for estimating the relationship among TPF and economic growth of Pakistan.

$$
Y_{t}=\beta_{0}+\beta_{1} T F P_{t}+\beta_{2} X_{i t}+\varepsilon_{t}
$$

Where, $Y_{t}$ is output, while $T F P_{t}$ represents total factor productivity and $X_{i t}$ is the set of control variables including labour force, physical capital, human capital and trade openness. $\beta^{\prime} s$ are parameters of interest to be estimated. Gross fixed capital formulation used as proxy of physical capital and secondary school enrollment as the proxy of human-capital respectively. So, the model to be estimated becomes,

$$
Y_{t}=\beta_{0} T F P_{t}+\beta_{1} L F_{t}+\beta_{2} T O_{t}+\beta_{3} S E_{t}+\beta_{4} G F C F_{t}+\varepsilon_{t}
$$




\section{Data and Construction of Variables}

For empirical analysis, present study utilized time series data from 1970 to 2013 obtained from World Development Indicator (WDI). All variables are in real term. Variables to be estimated and their definitions are given in the table below.

Table 1: Variables and definitions

\begin{tabular}{|l|l|c|}
\hline Variable & Description & Measurement \\
\hline$Y_{t}$ & Real Gross Domestic Product & Annual percent \\
\hline$T F P_{t}$ & Total Factor Productivity & -------- \\
\hline$L F_{t}$ & Labour Force & Millions(LCU) \\
\hline$T O_{t}$ & Trade Openness & Percentage of GDP \\
\hline$S E_{t}$ & Secondary School Enrollment Proxy For Human Capital & --------- \\
\hline$G F C F_{t}$ & Gross Fixed Capital Formulation Proxy For Physical Capital & Millions(LCU) \\
\hline
\end{tabular}

Source: World Bank, World Development Indicators. LCU denotes local currency units

\section{Econometric Methodology}

\section{Unit Root Testing}

If "variables in the regression model are non-stationary then the standard t-ratios will not follow tdistribution. Time series data has non-stationarity problem, therefore testing for stationarity of data is a prerequisite as first stage. There are various techniques used to investigate the presence or absence of unit root, present study will utilize Augmented Dickey Fuller (ADF)" test.

\section{Augmented Dickey Fuller Test}

Following equations show Augmented Dickey Fuller (ADF) unit root test.

Without "constant and trend; $X_{t}=\sigma X_{t-1}+\varepsilon_{t}$

With constant and no trend; $X_{t}=\alpha+\sigma X_{t-1}+\varepsilon_{t}$

With constant and trend; $\quad X_{t}=\alpha+\sigma X_{t-1}+\beta T+\varepsilon_{t}$

Where $X_{t}$ is related time-series, $\alpha$ is constant (intercept), T is time trend and $\varepsilon_{t}$ is disturbance.

Transforming above equations in difference by subtracting $X_{t-1}$ from both sides.

Without constant and trend; $\Delta X_{t}=\pi X_{t-1}+\varepsilon_{t}$

With constant and no trend; $\Delta X_{t}=\alpha+\pi X_{t-1}+\varepsilon_{t}$

With constant and trend; $\quad \Delta X_{t}=\alpha+\pi X_{t-1}+\beta T+\varepsilon_{t}$

Where $\Delta X_{t}=X_{t}-X_{t-1}$ and $\pi=\sigma-1$. The null hypothesis is that variable has unit root against alternative of no unit root in the series".

\section{Vector Auto Regression (VAR)}

To release linear interdependencies among time series data this study incorporates Vector Auto Regression(VAR). It simplifies the auto regression models by permitting more than one evolving variables in the model. Another simplicity of VAR model is that it does not need as much material about forces inducing a variable as structural models do with simultaneous equations. 


\section{Johansen Test of Co-Integration}

Present study used the Johansson and Juselius test of co-integration (1990) that is constructed on Vector Error Correction Model (VECM). Because of its advantages on other procedures such as Engle and Granger (1987) and Auto Regressive Distributed Lag Model (ARDLM) we prefer this technique in our analysis. The two series in Johanson procedure are supposed to be co-integrated when their linear combination of I (1) become $\mathrm{I}(0)$. Co-integration technique also helps us in finding general stochastic trend as well as long-run relationship between the variables. It is also useful in forecasting long run and separates short run. In co-integration it is assumed that variables are endogenous. Secondly, it is based on same order of integration. The estimation of long run relationship is next step of Johanson co-integration test. The equation of Johansen technique is as follows:

$$
\Delta Y_{t}=\delta+\sum_{i=1}^{k-1} \Gamma_{\mathfrak{i}} \Delta Y_{t-i}+\prod Y_{t-k}+\varepsilon_{t}
$$

Where, $\mathrm{Y}$ is vector of variables column, $\Gamma$ and $\Pi$ representing coefficient metrics, $\Delta$ represents change operator, k represents lag length, $\delta$ represents constant and $\varepsilon_{t}$ the error term. To analyze whether long run relationship exists among variables Johanson co-integration technique presents two steps. These steps are as under:

\section{Maximum Eigen Values}

$$
\lambda_{\max }(r, r+1)=-T \ln \left(1-\hat{\lambda}_{\mathrm{r}+1}\right)
$$

Another is

Trace Test

Where,

$$
\lambda_{\text {trace }}(r)=-T \sum_{l=r+1}^{n} \ln \left(1-\hat{\lambda}_{r+1}\right)
$$
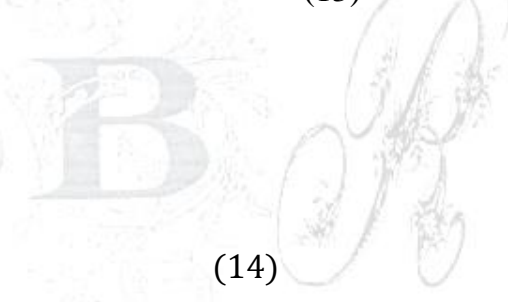

$\hat{\lambda}_{i}$ is "the estimated value characteristics roots. $\mathrm{T}$ is total number of observations and $\mathrm{r}$ is number of Cointegration vectors.

To catch up with the number of co-integration vectors trace-test and maximum-Eigen-value test were performed. For trace-test, null hypothesis is that there happens maximum " $r$ " co-integrating vectors for example $(r=0,1,2,3,4,5,6, \ldots)$ and for maximum Eigen value, the null hypothesis is tested against its alternative hypothesis.

\section{Error Correction Model (ECM)}

According to Granger-representative-theorem (GRT) data effective error-correction-representation always present in series of variables; if Co-integration of variable are found in order I (1). Granger (1987) stated that error-correction-model would be built, likewise once Co-integration established between the variables in VAR leads to evaluate and specify that ECM which counting error correction term that used to investigate dynamics of model. The speed of adjustment of instability in equilibrium of long-run is influenced by size of error-correction term". For analysis, Error-Correction-equations are given as under; 


$$
\begin{gathered}
\Delta G D P_{t}=\theta_{o}+\sum_{i=1}^{\kappa} \theta_{\iota} \Delta G D P_{t-1}+\sum_{i=0}^{\kappa} \beta_{i} \Delta T F P_{t-i}+\sum_{i=0}^{\kappa} \gamma_{i} \Delta G R C F_{t-i}+\sum_{i=0}^{\kappa} \delta_{i} \Delta S C E_{t-i}+\sum_{i=0}^{\kappa} \vartheta_{i} \Delta L F_{t-i} \\
+\sum_{i=0}^{\kappa} \sigma_{i} \Delta T O_{t-i}+\varphi
\end{gathered}
$$

Where,

$\Delta$ is "difference, $\varphi$ the coefficient of error correction term, $\hat{\varepsilon}_{t-1}$ the error correction term $\mu_{t}$ the residual and $k$ is optimum number of lags of the variable".

\section{Wald Test}

Agresti (1990) and Polit (1996) suggested a framework called Wald test. If the results from the Wald test are significant for a specific independent variable or set of these variables, formerly it would be decided that all the parameters related with these variables are non-zero, on basis of this result, variables would be involved in the empirical model. In case of insignificant Wald test, explanatory variables canbe omitted from model. For significance of parameters, Altman (1991) used a t-test, when seeing a one independent variable. The Wald-Statistic will be square of the t-statistic. So, that it will gives accurate statistics for unique parameter.

$$
W=n(b)^{\prime}\left(\frac{\partial \delta}{\partial \beta} V \frac{\partial \delta}{\beta^{\prime}}\right)^{-1} \delta(b)
$$

Where, " $n$ " is number of observations, " $b$ " is unrestricted parameter estimates and "V" is estimate of variance of $b$.

\section{Granger Causality Test}

Granger-Causality Test is used to study the direction of causation (Gujrati and Porter, 2009). This test contains following equations;

$$
\begin{aligned}
& X_{t}=" \sum_{i=1}^{n} \alpha_{i} Y_{t-i}+\sum_{j=1}^{n} \beta_{j} X_{t-j}+\mu_{1 t} \\
& Y_{t}=\sum_{i=1}^{n} \gamma_{i} Y_{t-i}+\sum_{j=1}^{n} \delta_{j} X_{t-j}+\mu_{2 t}
\end{aligned}
$$

Where $X_{t}$ and $Y_{t}$ are variables which must be stationary, $\mu_{1 t}$ and $\mu_{2 t}$ are disturbances and it is assumed that they are not correlated".

\section{Results and Discussion}

This section of the study delivers empirical results of the model. The initial step in the co-integration is testing stationary of time series data. Augmented Dickey Fuller (ADF) test has been used for testing stationary of variables. The null hypothesis is that there is unit root. The results of ADF are presented below.

Table 2 presents the results of ADF for all the series and revealed that the entire variable are non-stationary at level and after taking the first difference the series become stationary at first difference, therefore, integrated of I (1) a necessary precondition for applying Johanson and Jusilius $(1988,1995)$ technique. Now we may move forward towards the second step of co-integration. 
Table 2: Augmented Dickey Fuller test

\begin{tabular}{|l|lc|cc|}
\hline \multirow{2}{*}{ Variables } & \multicolumn{3}{|c|}{ Level } & \multicolumn{2}{c|}{$\mathbf{1}^{\text {st }}$ difference } \\
\cline { 2 - 5 } & WOT & WT & WOT & WT \\
\hline GDP & -1.196 & -0.500 & -4.664 & $-4.915^{* * *}$ \\
TFP & -0.207 & -2.211 & -5.639 & $-5.590^{* *}$ \\
LF & -1.616 & -1.638 & -4.995 & $-5.196^{* *}$ \\
TO & -3.583 & -3.360 & -7.630 & $-7.904^{* *}$ \\
SE & 0.203 & -1.991 & -5.351 & $-5.373^{* *}$ \\
GFCF & -1.422 & -0.741 & -4.985 & $-5.171^{* *}$ \\
\hline
\end{tabular}

Note: $5 \%$ critical values WT, with trend WOT without trend.

\section{Lag Length Selection Criteria}

Lag length selection is important diagnostic while estimating relationships using Johansen Test of Cointegration regression. According to our results all criteria except SC recommends the lag length 4 . So, to continue the next stage, lag length of 4 is selected. Lag length selection criteria is shown in table 3 below.

Table3: Lag-Length Decision Criteria

\begin{tabular}{|llllll|}
\hline Lag & L.R & F.P.F & A.I.C & S.C & H.Q \\
\hline 0 & N.A & $1.46 \mathrm{E}-08$ & -1.0162 & $-0.7629^{*}$ & -0.924 \\
1 & 491.087 & $3.11 \mathrm{E}-14$ & -14.097 & -12.324 & -13.456 \\
2 & 51.353 & $3.18 \mathrm{E}-14$ & -14.199 & -10.906 & -13.008 \\
3 & 46.596 & $2.97 \mathrm{E}-14$ & -14.618 & -9.8052 & -12.878 \\
4 & $53.533^{*}$ & $1.13 \mathrm{E}-14 *$ & $-14.387^{*}$ & -10.054 & $-14.097^{*}$ \\
\hline
\end{tabular}

Note: * shows the lag length selected by each criteria.

\section{Johansen Test of Co-Integration}

With the conformation of stationarity properties of the data set and lag length selection now we are able to apply co-integration test. Johansson's system for co-integration uses the two tests for choosing the appropriate number of co-integrating vectors or long run association among variables. Trace-test and Maximum-Eigen Value Test will be utilized for choosing the vicinity of long run association among the variables. Results of Trace test are presented in table 4 which confirms the existence of 5 co-integrating vectors at 5\% significance level and results of Maximum Eigen value are in table 5.

Table 4: The Results of Trace-Test

\begin{tabular}{|l|l|l|l|l|}
\hline No of CE(s) & Eigenvalue & Trace statistic & Critical value & Prob.** \\
\hline None* & 0.94 & 107.14 & 36.64 & 0.00 \\
\hline At most $1^{*}$ & 0.86 & 74.68 & 30.44 & 0.00 \\
\hline At most 2* & 0.63 & 38.58 & 24.16 & 0.00 \\
\hline At most 3* & 0.46 & 24.03 & 17.98 & 0.00 \\
\hline At most 4* & 0.32 & 14.77 & 11.23 & 0.02 \\
\hline At most 5 & 0.09 & 3.49 & 4.13 & 0.09 \\
\hline
\end{tabular}

Note: *Denote the rejection of null hypotheses at $5 \%$ level.

With the above results shown in the table 4 showed the significant values and at least 5 co-integration equations indicating that there is long run relationship in TFP and economic growth of Pakistan along with its control variables. 
In Johansson and Juselius co-integration procedure there must be at least one co-integrated vector in model indicating the application of co-integration. As the trace test tends to have more distorted sizes whereas there power is in prior to that of the maximum eigenvalue test. The results of maximum Eigen value are presented as follows.

Table 5: Results of Maximum-Eigen Value test

\begin{tabular}{|l|l|l|l|l|}
\hline No. of CE(s) & Eigen-value & Max-Eigen Statistic & Critical Value & Prob-value \\
\hline At most 1* & 0.86 & 155.54 & 60.07 & 0.00 \\
\hline At most 2* & 0.63 & 80.87 & 640.18 & 0.00 \\
\hline At most 3* & 0.46 & 42.29 & 24.28 & 0.00 \\
\hline At most 4* & 0.32 & 18.26 & 12.33 & 0.00 \\
\hline At most 5 & 0.09 & 3.486 & 4.13 & 0.08 \\
\hline Note: *Donate rejection of the null hypotheses & \\
\hline
\end{tabular}

\section{The Error Correction Model}

For the purpose of short run analysis Error Correction Mechanism (ECM) is being applied in the model. The results as given below in Table 6 .

Table 6: Results of ECM

\begin{tabular}{|c|c|c|c|c|}
\hline $2(52)$ & Coefficient & Std. Error & t-Statistic & Prob. \\
\hline 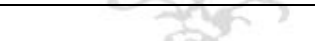 & -2.28 & 0.49 & -4.58 & 0.00 \\
\hline D(Trade OF_GDP) & & & & \\
\hline $\mathrm{D}(\mathrm{SSE})$ & 1.74 & 1.04 & 1.68 & 0.12 \\
\hline $\mathrm{D}(\mathrm{TFP})$ & -117.52 & 36.38 & -3.22 & 0.02 \\
\hline $\mathrm{D}(\mathrm{LF})$ & -71.19 & 28.82 & -2.46 & 0.04 \\
\hline $\mathrm{D}($ Trade of GDP)(-1) & 20.92 & 15.84 & 1.32 & 0.22 \\
\hline D (Trade of GDP)(-2) & 0.59 & 0.28 & 2.14 & 0.06 \\
\hline $\mathrm{D}($ Trade of GDP $)(-3)$ & 0.44 & 0.22 & 1.92 & 0.08 \\
\hline D (Trade of GDP)(-4) & 0.24 & 0.18 & 1.36 & 0.22 \\
\hline $\mathrm{D}(\mathrm{SSE})(-1)$ & 0.12 & 0.14 & 0.82 & 0.44 \\
\hline $\mathrm{D}(\mathrm{SSE})(-2)$ & 8.29 & 1.89 & 4.38 & 0.02 \\
\hline $\mathrm{D}(\mathrm{SSE})(-3)$ & 10.06 & 3.42 & 2.94 & 0.02 \\
\hline $\mathrm{D}(\mathrm{SSE})(-4)$ & 2.52 & 2.34 & 1.06 & 0.32 \\
\hline $\mathrm{D}(\mathrm{TFP})(-1)$ & -3.14 & 1.74 & -1.80 & 0.10 \\
\hline $\mathrm{D}(\mathrm{TFP})(-2)$ & -106.42 & 35.64 & -2.98 & 0.01 \\
\hline $\mathrm{D}(\mathrm{TFP})(-3)$ & -186.92 & 65.76 & -2.84 & 0.01 \\
\hline $\mathrm{D}(\mathrm{TFP})(-4)$ & -63.68 & 52.78 & -1.20 & 0.25 \\
\hline $\mathrm{D}(\mathrm{LF})(-1)$ & 79.84 & 40.32 & 1.98 & 0.07 \\
\hline $\mathrm{D}(\mathrm{LF})(-2)$ & -84.00 & 46.92 & -1.79 & 0.10 \\
\hline $\mathrm{D}(\mathrm{LF})(-3)$ & -270.18 & 77.00 & -3.50 & 0.00 \\
\hline $\mathrm{D}(\mathrm{LF})(-4)$ & -326.99 & 93.02 & -3.52 & 0.00 \\
\hline $\mathrm{D}(\mathrm{GFCF})$ & -172.16 & 64.42 & -2.68 & 0.02 \\
\hline $\mathrm{D}(\mathrm{CFGF})(-1)$ & -14.12 & 12.50 & -1.12 & 0.28 \\
\hline $\mathrm{D}(\mathrm{CFGF})(-2)$ & -28.49 & 11.54 & -2.46 & 0.04 \\
\hline $\mathrm{D}(\mathrm{CFGF})(-3)$ & -9.36 & 10.22 & -0.92 & 0.38 \\
\hline $\mathrm{D}(\mathrm{CFGF})(-4)$ & 11.34 & 7.48 & 1.52 & 0.16 \\
\hline $\mathrm{D}(\mathrm{GDP})(-1)$ & -132.66 & 41.38 & -3.20 & 0.02 \\
\hline $\mathrm{D}(\mathrm{GDP})(-2)$ & -103.38 & 43.98 & -2.36 & 0.04 \\
\hline $\mathrm{D}(\mathrm{GDP})(-3)$ & -42.24 & 31.34 & -1.34 & 0.22 \\
\hline $\mathrm{D}(\mathrm{GDP})(-4)$ & -32.64 & 26.54 & -1.24 & 0.24 \\
\hline DGDP) & 41.52 & 10.96 & 3.78 & 0.00 \\
\hline
\end{tabular}

Note: Granger Causality test results from data sample 1980-2019 
Econometric validity for a short run equilibrium is indicated by ECM equation $\mathrm{C} 1$ to be negative and significant. The minus sign indicating that there is long run causality running from independent variable to dependent variable. ECM tells us the speed with which our model runs to equilibrium following an exogenous stock. In above table 6, significance value of error term is obtained 0.001 that reflect the speed of adjustment is very slow that shows, for human capital it adjusts very slowly in case of Pakistan.

\section{Coefficient Diagnostics: Wald-Test}

Wald-test has been used to find out significance of explanatory variables.

Table 7: Normalized Restriction $(=0)$

\begin{tabular}{|lccc|}
\hline & C. Value & Std. Err. & Prob. \\
\hline C(1) & & & \\
C (2) & -2.28 & 0.49 & 0.00 \\
C (3) & 1.74 & 1.04 & 0.00 \\
C(4) & -1.18 & 36.38 & 0.02 \\
C (5) & -71.19 & 28.8 & 0.01 \\
C(6) & 20.92 & 15.84 & 0.00 \\
\hline
\end{tabular}

Note: Wald test results

With normalized restriction $(=0)$ it is found that all variables are significant and show rejection of null hypothesis so these variables cannot be dropped from the model.

\section{Granger Causality Test}

Granger-Causality test has been applied among variables and results have been incorporated in table 8 below.

Table 8: Granger Causality Test Results

\begin{tabular}{|c|c|c|c|c|c|}
\hline \multirow{2}{*}{ Pairwise Hypothesis } & \multicolumn{3}{|c|}{ F-Statistics } & \multirow[b]{2}{*}{ Decision } & \multirow{2}{*}{ Type of causality } \\
\hline & Obs. & & P-value & & \\
\hline $\mathrm{SCE} \rightarrow \mathrm{TO}$ & 41 & 0.92 & 0.29 & DNR H0 & No causality \\
\hline $\mathrm{TO} \rightarrow \mathrm{SCE}$ & 41 & 1.28 & 0.48 & DNR H0 & No causality \\
\hline $\mathrm{TFP} \rightarrow \mathrm{TO}$ & 41 & 0.86 & 0.22 & DNR H0 & No causality \\
\hline $\mathrm{TO} \rightarrow \mathrm{TFP}$ & 41 & 1.58 & 0.52 & DNR HO & No causality \\
\hline $\mathrm{LF} \rightarrow \mathrm{TO}$ & 41 & 0.76 & 0.76 & DNR HO & No causality \\
\hline $\mathrm{TO} \rightarrow \mathrm{LF}$ & 41 & 0.38 & 0.94 & DNR H0 & No causality \\
\hline $\mathrm{GFC} \rightarrow \mathrm{TO}$ & 41 & 0.12 & 0.84 & DNR H0 & No causality \\
\hline $\mathrm{TO} \rightarrow \mathrm{GFCF}$ & 41 & 0.28 & 0.14 & DNR HO & No causality \\
\hline $\mathrm{GDP} \rightarrow \mathrm{TO}$ & 41 & 2.02 & 0.48 & DNR H0 & No causality \\
\hline $\mathrm{TO} \rightarrow \mathrm{GDP}$ & 41 & 0.84 & 0.84 & DNR H0 & No causality \\
\hline $\mathrm{TFP} \rightarrow \mathrm{SSE}$ & 41 & 0.28 & 0.88 & DNR H0 & No causality \\
\hline $\mathrm{SSE} \rightarrow \mathrm{TFP}$ & 41 & 0.24 & 0.02 & Reject H0 & Uni-directional causality \\
\hline $\mathrm{LF} \rightarrow \mathrm{SSE}$ & 41 & 3.62 & 0.02 & Reject H0 & Bi-directional causality \\
\hline $\mathrm{SSE} \rightarrow \mathrm{LF}$ & 41 & 4.38 & 0.06 & Reject H0 & Bi-directional causality \\
\hline $\mathrm{GFCF} \rightarrow \mathrm{SSE}$ & 41 & 2.86 & 0.02 & Reject HO & Bi-directional causality \\
\hline $\mathrm{SSE} \rightarrow \mathrm{GFCF}$ & 41 & 4.40 & 0.06 & Reject H0 & Bi-directional causality \\
\hline
\end{tabular}




\begin{tabular}{llllll|}
\hline GDP $\rightarrow$ SSE & 41 & 4.19 & 0.01 & Reject H0 & Bi-directional causality \\
SSE $\rightarrow$ GDP & 41 & 3.26 & 0.04 & Reject H0 & Bi-directional causality \\
LF $\rightarrow$ TFP & 41 & 3.69 & 0.02 & Reject H0 & Bi-directional causality \\
TFP $\rightarrow$ LF & 41 & 3.28 & 0.02 & Reject H0 & Bi-directional causality \\
GDP $\rightarrow$ TFP & 41 & 3.84 & 0.02 & Reject H0 & Bi-directional causality \\
TFP $\rightarrow$ GDP & 41 & 3.56 & 0.02 & Reject H0 & Bi-directional causality \\
GFCF $\rightarrow$ LF & 41 & 6.09 & 0.00 & Reject H0 & Bi-directional causality \\
LF $\rightarrow$ FCF & 41 & 0.24 & 0.08 & Reject H0 & Uni-directional causality \\
GDP $\rightarrow$ LF & 41 & 0.69 & 0.56 & DNR H0 & No causality \\
LF $\rightarrow$ GDP & 41 & 0.12 & 0.94 & DNR H0 & No causality \\
GDP $\rightarrow$ GFCF & 41 & 0.79 & 0.50 & DNR H0 & No causality \\
FGCF $\rightarrow$ GDP & 41 & 6.08 & 0.00 & Reject H0 & Uni-directional causality \\
\hline
\end{tabular}

Note: $\alpha=0.05$, Decision rule: reject H0 if P-value <0.05. Key: DNR = Do not reject; $\rightarrow=$ does not Granger cause.

Here above fifteen VAR models have been formulized to test Pairwise Granger causality between economic indicators on the basis of theory discussed in previous section above results are found. It can be see that following bi-directional and uni-directional causality occurs among some particular economic indicators: Secondary school enrollment Granger causes total factor productivity, labour force Granger causes GFCF and GFCF causes GDP. The bi-directional causality results are: labor force Granger causes Secondary school enrollment, secondary school enrollment Granger cause labor force. Gross fixed capital formation Granger Causes Secondary school enrollment, Secondary school enrollment Granger cause Gross fixed capital formation. Labor force Granger causes TFP, as TFP Granger cause labour force. GDP Granger causes TFP and TFP Granger causes GDP. The results here approve the former co-integration analysis that shows we have at least five co-integrated equations in the model.

\section{Conclusion}

The study was intended to investigate TFP and growth nexus for Pakistan using latest time series data. It reported that influence of TFP was much more significant in attaining the high growth fluctuates from 5.6 percent in the period 1973-77 to 6.6 percent in the period 2003-2006. In other words the economic growth of Pakistan through 2003-2006, was essentially determined by the enrichment of TFP and less growth through the 1970s and 1990s was mainly due to a huge decline in TFP. Pakistan have reached at the extraordinary economic growth level during the 1980s also, that was to an amount similarly contributed by both TFP and inputs availability.

The expansionary and contractionary monetary and fiscal policies are responsible for the less growth of TFP in period 1992-2002 and higher TFP in the 2002-06 eras respectively (Khalil 2007). Human capital enhancement accounted positively to the economy of Pakistan. This shows the significance of floating human capital endowment and economic extension services to the labour force to realize growths in TFP in economy of Pakistan. After 2000 the growth in TPF is mainly attributed by the development in the human capital. There are some other determinants of TFP like exports of industrial goods and fiscal policy incentives canbe researched for their roles in the course of sustained and inclusive growth processes.

\section{Acknowledgment}

This research has received no specific funding. 


\section{References}

Afzal, M. (2006). Some New Production Measurement Methods for Large-Scale Manufacturing Sector of Pakistan. PhD Dissertation (unpublished) submitted to National College of Business Administration \& Economics.

Aghion, P. \& P. Howitt. (1992). A Model of Growth through Creative Destruction. Econometrica, 60(2), 323-351.

Agresti, A. (1990). Categorical Data Analysis. John Wiley and Sons, New York. Altman D.G. (1991) Practical Statistics for Medical Research. Chapman \& Hall, London.

Ahmed, H. K., Muhammad Ilyas., Tahir M., \& Muhammad, A. (2010). Exploring the effect of Total Factor Productivity growth on future output. Pakistan Economic and Social Review, 48 (1), 105-122.

Anwar, M. M., Khan, G. Y., \& Khan, S. J. I. (2019). Investigating of the Inclusiveness in the Economic Growth of Pakistan. The Journal of Economy and Market Communication Review (Emc Review)Časopis Za Ekonomiju, 17(1), 1-10.

Arrow, K. (1962). The Economic Implications of Learning by Doing. The review of Economic Studies, 29(3), 155-173.

Aslam, N., Ghulam, Y. K., \& Muhammad, S. H. (2019). Exploring the Role of Fiscal Decentralization in Capital formation: Empirical Evidence from Pakistan. European Online Journal of Natural and Social Sciences: Proceedings, 8(4S), 146-154.

Atkinson, A. B., \& Stiglitz. J. E. (1969). A new view of technological change. Economic Journal, 79(315), 573-578.

Baldwin, J. R., \& Rafiquzzaman, M. (1996). Structural Change in the Canadian Manufacturing Sector: 1970-1990. Analytical Studies Branch Research Paper Series, Statistics Canada. https://www150.statcan.gc.ca/n1/en/catalogue/11F0019M1994061

Bartelsman, E. J., \& P. J. Dhrymes. (1998). "Productivity dynamics: U.S. manufacturing plants, /19721986." Journal of Productivity Analysis, 9(1), 5-34.

Bartelsmann, E.J., van Leeuwen, G. \& H.R. Nieuwenhuijsen. (1996). “Advanced Manufacturing Technology and Firm Performance in the Netherlands", Netherlands Official Statistics, 11(Autumn, 1996), 40-51.

Basti, Y. \& Akin, A. (2008). The Comparative Productivity of the Foreign-Owned Companies in Turkey: A Malmquist Productivity Index Approach. International Research Journal of Finance and Economics, 22, 1450-2887.

Benhabib, J. \& M.M. Spiegel. (1994). The role of human capital in economic development: Evidence from aggregate cross-country data. Journal of Monetary Economics, 34(2), 143-173.

Bjurek, H. \& Durevall, D. (2000). Does Market liberalization Increase Total Factor Productivity? Evidence from the Manufacturing Sector in Zimbabwe. Journal for Southern African Studies, 26(3), 463-479.

Burki, A. A., \& Mahmood, H. K. (2005). Effects of Allocative Inefficiency on Resource Allocation and Energy Substitution in Pakistan's manufacturing. Lahore University of Management Sciences (CMER Working Paper No. 04-30).

Chanda, A. \& C-J. Dalsgaard. (2003). "Dual Economies and International Total Factor Productivity Differences", Economic Policy Research Unit Working Paper, University of Copenhagen.

Chaudhry, A. A. (2009), Total Factor Productivity Growth in Pakistan: An analysis of the agriculture and manufacture sector. Lahore Journal of Economics, 14 (Issue Special Edition, Sept 2009), 1-16.

Chen, D.H.C., \& C.J. Dahlman. (2004). "Knowledge and Development: A Cross-Section Approach", Policy Research Working Paper, No. 3366, Washington, DC: World Bank.

Coe, David. T., \& Helpman, Elhanan. (1995). International Research and Development Spillovers. NBER Working Paper No. 4444.

Comin, D., \& G. Mark. (2006). Medium-term business cycles. American Economic Review, 96(3), 523551.

Comin, D., \& S. Mulani. (2006). A Theory of Growth and Volatility at the Aggregate and Firm Level. NBER Working Paper No. 11503. 
Comin, D., B. Hobijn., \& E, Rovito. (2006). Five Facts you need to Know about Technology Diffusion. NBER Working Paper No. 11928.

Crépon, B. E., Duguet, E. \& J. Mairesse. (1998). "Research, Innovation, and Productivity: An Econometric Analysis at the Firm Level", NBER Working Paper No. 6696, Cambridge, MA: NBER.

Diaz, M. A., \& Sanchez, R. (2008). Firm Size and Productivity in Spain: A Stochastic frontier analysis. Small business Economics, 30, 315-323. https://link.springer.com/article/10.1007/s11187-007-9058x\#citeas

Dutta, D., \& Ahmed, N. U. (2006). Trade Liberalization and Industrial Growth in Pakistan: A Cointegration Analysis. Department of Economics, University of Sydney, Australia.

Edwards, S. (1997). “Openness, Productivity and Growth: What Do We Really Know? NBER Working Papers, No. 5978.

Färe, R., S. Groskopf., \& C. A. Pasurka, Jr. (2001). “Accounting for Air Pollution Emissions in Measures of State Manufacturing Productivity Growth", Journal of Regional Science, 41(3), 381-409.

Färe, R., S. Groskopf., \& Margaritis, D. (2001). Productivity Trends in Australian and New Zealand Manufacturing. Australian Economic Review, 34 (2), 125-34.

Fare, R., S. Groskopf., and Lee, W. F. (1995). Productivity in Taiwanese Manufacturing Industries. Applied Economics. 27(3), 259-265.

Fatima, A., Alam, S., \& Butt, M. S. (2003). International Trade and TFP Growth in Pakistan: A Multivariate Causality Analyses. Indian Journal of Quantitative Economics, 18(1\&2), 31-54.

Fu, X. (2005). Exports, Technical Progress and Productivity Growth in a Transition Economy: A Nonparametric Approach for China, Applied Economics, 37(7), 725-39.

Geroski, P.A. (1991). Market Dynamics and Entry, Oxford: Basil Blackwell.

Granger, C.W.J. (1969). Investigating Causal Relations by Econometric Models and Cross Spectral Methods. Econometrica, 37(3), 424-35.

Grossman, G., \& E. Helpman. (1994). "Endogenous Innovation in the Theory of Growth." Journal of Economic Perspectives, 8(1), 23-44.

Hahn, S. (2001), "Firm Dynamics and Productivity Growth: A Review of Micro Evidence from OECD

Hall, R. E., \& Jones, C. I. (1999) “The Productivity of Nations,” NBER Working Paper No5812. https://web.stanford.edu/ chadj/HallJonesQJE.pdf

Hall, R., and Jones, C. I. (1999). Why Do Some Countries Produce So Much More Output per Worker than Others? Quarterly Journal of Economics, 114(1), 83-116.

Han, M. J. (2003). Testing the Predictive Ability of Measures of Total Factor Productivity Growth. Unpublished Ph.D. dissertation, University of Missouri-Columbia,

IMF. (2007). World Economic Outlook, (Washington DC 114F October, 2007).

Jones, C.I. (1995). 'Time Series Tests of Endogenous Growth Models', Quarterly Journal of Economics, $110(2), 495-525$.

Khan, G. Y., Mehboob, S., \& Lopez, L. B. (2018). Deindustrialization and Economic Growth: Empirical Evidence From Pakistan. Asian Journal of Economic Modelling, 6(4), 462-475.

Khan, G. Y., Sarfraz, Ahmed, Shabir Saba, \& Muhammad Saim Hashmi (2019). Empirical Evidence of Banking Sector Development and Economic Growth in Pakistan: A Time Series Approach. Contemporary Dilemmas: Education, Politics and Values Journal, Special Edition, 1-20

Khan, S. U. (2006), Macroeconomic determinants of total factor productivity in Pakistan. Working Paper No. 10, State Bank of Pakistan.

Kim, Jong-Il., \& Laurence J. Lau. (1994). The sources of economic growth of East Asian newly industrialized countries. Journal of the Japanese and International Economics, 8(3), 235-271.

Klenow, P., \& A. Rodriguez-Clare. (1997). The Neoclassical Revival in Growth Economics: Has it gone too far? NBER Macroeconomics Annual, B. Bernanke and J. Rotembergeds, Cambridge, MA: MIT Press, 73-102.

Lewis, A. W. (1980). "The Slowing Down of the Engine of Economic Growth." American Economic Review, 70(4) 555-564.

Mahadevan, R. (2000). How Technically Efficient is Singapore's Manufacturing Industries? Applied Economics, 32(15), 2007-2014. 
Mahmood, T., Ghani, E., \& Din, M. (2007). Efficiency of Large Scale Manufacturing In Pakistan: production Frontier Approach. Pakistan Development Review, 45(4), 689-700.

Mayer, J. (2001). "Technology Diffusion, Human Capital and Economic Growth in Developing Countries". Discussion Papers, No. 154, Geneva: United Nations Conference on Trade and Development.

McGuckin, R. .H., Streitwieser. M., \& M. Doms. (1998). “Advanced Technology Usage and Productivity Growth". Economic of Innovation and New Technology, 7(1), 1-26.

Mengistae, T., \& C. Pattillo. (2004). "Export Orientation and Productivity in Sub-Saharan Africa". IMF Staff Papers, 51(2), 327-353.

Miller, S.M., \& Upadhya, M.P. (2000). The Effect of Openness, Trade Orientation, and Human Capital on Total Factor Productivity. Journal of Development Economics, 63(2), 399-423.

Pack, H. (1988). Industrialization and Trade in Chenery, H. and T. N. Srinivasan (eds.), Handbook of Development Economics, Amsterdam, North Holland.

Pasha, H. A., A. G. Pasha., \& K. Hyder. (2002). The Slowing Down of the Growth of Total Factor Productivity in Pakistan. Karachi Social Policy and Development Center.

Polit, D. (1996). Data Analysis and Statistics for Nursing Research. Appleton and Lange, Stamford, Connecticut.

Rauf, A., Sher, A., Ghulam, Y. Q., Dilshad, A., \& Numera, A. (2017). Fiscal Decentralization and Delivery of Public Services: Evidence from Education Sector in Pakistan. Studies in Business \& Economics, 12(1), 174-184.

Romer, P. (1990). Endogenous Technological Change. The Journal of Political Economy, 98(5), 71-102.

Sabir, M. \& Ahmed, Q. M. (2002). Macroeconomic Reforms and Total Factor Productivity Growth in Pakistan: An Empirical Analysis. Quebec: $56^{\text {th }}$ International Atlantic Economic Conference.

Solow, R. (1956). A Contribution to the Theory of Economic Growth. Quarterly Journal of Economics, 70(1), 65-94.

Solow, R. (1957). Technical Change and the Aggregate Production Function. Review of Economics and Statistics, 39(3), 312-320.

Ulku, H. (2004). R\&D, Innovation, and Economic Growth: An Empirical Analysis. IMF Working Paper, 04(185), Washington, DC: International Monetary Fund.

Ullah, K. S. (2006). Macro Determinants of Total Factor Productivity in Pakistan. SBP Research Bulletin: 2

Van, B. J. (2003). Exporting Raises Productivity in Sub-Saharan African Manufacturing, NBER Working Paper Series, No. 10020, Cambridge, MA: NBER.

Wang, H., \& C. Lawson. (2003). "Growth Accounting vs. Regression in a Cross country TFP Exercise," Centre for Public Economics, University of Bath.

Wizarat, S. (1981). “Technological Change in Pakistan's Agriculture: 1953-54 to 1978-79." Pakistan Development Review, 20(4), 427-445.

Wizarat, S. (1989). "Sources of Growth in Pakistan's Large Scale Manufacturing Sector: 1955-56 to 198081." Pakistan Economic and Social Review, 27(2), 139- 159.

Young A. (1995). The Tyranny of Numbers: Confronting the Statistical Realities of the East Asian Experiences. The Quarterly Journal of Economics, 110 (8), 64-79.

Young, A. (1992). A tale of two cities: Factor accumulation and technological change in Hong Kong and Singapore. NBER Macroeconomics Annual, the MIT Press.

Zaidi, S. A. (2008). The Political Economy of Military Rule in Pakistan: ISAS working paper.No:31. 